p-ISSN: 2774-1907; e-ISSN: 2774-1915; Volume 1, Nomor 1, Nopember 2020

\title{
ANALISIS PARADIGMA PEMBANGUNAN DI INDONESIA
}

\section{ANALISYS OF DEVELOPMENT PARADIGM IN INDONESIAN}

\author{
Renny Puteri \\ Harapan Rani ${ }^{1}$ \\ Arlisaka Madani Group \\ email: \\ rennyranirasyid@gmail. \\ com
}

IJI Publication p-ISSN: 2774-1907 e-ISSN: 2774-1915 Vol.1, No.1, pp.40-52, Nopember 2020

Unit Publikasi Ilmiah
Intelektual Madani
Indonesia

Abstrak: Penelitian ini bertujuan untuk mengetahui dan menganalisis paradigma pembangunan di Indonesia dan paradigm yang tepat untuk pembangunan Indonesia. Penelitian ini merupakan penelitian kualitatif dengan metode analisis yang digunakan adalah Analisa Diskursus Kritis (Critical Discourse Analysis) yang mengasumsikan bahwa semua objek dan tindakan adalah penuh makna secara khusus, dan setiap diskursus menunjukkan konstruksi sosial dan politik pada obyek yang diamati. Langkah peran peneliti adalah menyajikan permasalahan, mengumpulkan data historis, mengekstrak kumpulan makna untuk disajikan kembali dalam bentuk analisis hasil kajian pustaka/konseptual. Hasil kajian mengambarkan bahwa paradigma pembangunan yang diterapkan di Indonesia dari masa orde, orde baru, hingga orde reformasi belum mampu menghantarkan bangsa Indonesia menjadi Negara atau bangsa yang berdaulat atas masyarakatnya. Di era yang serba terbuka ini, masyarakat semakin kritis terhadap kebijakan pembangunan yang dilaksanakan oleh Pemerintah maka paradigma yang dianggap tepat untuk pembangunan Indonesia adalah Pembangunan Berkelanjutan (Sustanaible Development). Konsep ini mengandung tiga aspek pemahaman, yakni 1) keberlanjutan lingkungan, 2) keberlanjutan ekonomi, 3) keberlanjutan sosial dengan indikator pembangunan berkelanjutan adalah: 1) Melestarikan sistem-sistem pendukung kehidupan dan keanekaragaman hayati, 2) Menjamin keberlanjutan penggunaan sumberdaya yang dapat diperbarui dan meminimkan penipisan sumberdaya yang tak dapat diperbarui, 3) Berusaha tidak melampaui daya dukung ekosistem.

Kata Kunci: Paradigma; Pembangunan Indonesia; Pembangunan Berkelanjutan.

Abstract: This study aims to identify and analyze the development paradigm in Indonesia and the right paradigm for Indonesia's development. This research is a qualitative research with the analytical method used is Critical Discourse Analysis which assumes that all objects and actions are full of special meaning, and each discourse shows a social and political construction on the object being observed. The step of the researcher's role is to present the problem, collect historical data, extract a collection of meanings to be presented again in the form of analysis of the results of a literature study/conceptual. The results of the study illustrate that the development paradigm applied in Indonesia from the New Order, to the Reformation Order has not been able to bring the Indonesian nation to become a state or nation that is sovereign over its people. In this open era, society is increasingly critical of development policies implemented by the Government, so the paradigm that is considered appropriate for Indonesia's development is Sustainable Development (Sustanaible Development). This concept contains three aspects of understanding, namely 1) environmental sustainability, 2) economic sustainability, 3) social sustainability with indicators of sustainable development are: 1) Preserving life support systems and biodiversity, 2) Ensuring the sustainable use of renewable resources and Minimizing depletion of non-renewable resources, 3) Trying not to exceed the carrying capacity of the ecosystem.

Keywords: Paradigm; Indonesian Development; Sustainable Development.

\section{PENDAHULUAN}

Pembangunan bangsa-bangsa di dunia mengalami beberapa pergeseran paradigma, yaitu mulai dari paradigma pertumbuhan, kesejahteraan, neoekonomi, ketergantungan (dependencia) sampai paradigma pembangunan manusia. Namun pada intinya, menurut Suryadi, ada tiga paradigma pembangunan yaitu: Pertama diawali dengan paradigma pertumbuhan (growth paradigm); kedua pergeseran dari paradigma pertumbuhan menjadi paradigma kesejahteraan (welfare paradigm); ketiga adalah paradigma pembangunan yang berpusat pada manusia (people centered development paradigm).

Paradigma merupakan cara pandang seseorang terhadap diri dan lingkungannya yang akan mempengaruhinya dalam berpikir (kognitif), bersikap (afektif) dan bertingkah laku (konatif). Paradigma juga dapat berarti seperangkat asumsi, konsep, nilai dan praktek yang diterapkan dalam memandang realitas dalam sebuah komunitas yang sama, khususnya dalam disiplin intelektual. 
Sedangkan pembangunan adalah proses perubahan ke arah kondisi yang lebih baik melalui upaya yang dilakukan secara terencana. (Kartasasmita, 1997). Berdasarkan pandangan tersebut, paradigma pembangunan dapat didefinisikan sebagai cara pandang terhadap suatu persoalan pembangunan yang dipergunakan dalam penyelenggaraan pembangunan baik pembangunan dalam arti sebagai proses maupun sebagai metode yang bertujuan untuk mencapai peningkatan kualitas kehidupan manusia dan kesejahteraan rakyat.

Teori pembangunan pun dalam perkembangannya semakin kompleks yang tidak terikat pada satu disiplin ilmu. (Bjorn, 1982). Adapun yang menjadi tujuan dari pembangunan antara lain : a). Peningkatan standar hidup (levels of living); b). Penciptaan berbagai kondisi yang memungkinkan tumbuhnya rasa percaya diri (self-esteem) seseorang dan c). Peningkatan kebebasan (freedom/democracy) setiap orang. (Todaro, 2000) Paradigma pembangunan selalu dan harus berubah dari waktu ke waktu, sesuai dengan tuntutan jaman dan permasalahan. Terjadinya krisis yang besar sering dan memaksakan munculnya paradigma baru. Tanpa paradigma baru, krisis yang sama dan lebih besar akan terjadi lagi.

Dalam sejarahnya Indonesia telah mengimplementasikan beberapa paradigma pembangunan yang ada di dunia dengan ciri khasnya masing-masing, mulai dari paradigma liberal yang erat kaitannya dengan modernisasi dan paradigma Marxis dengan konsep pemberdayaannya. Paradigma pembangunan yang dijalankan tersebut merupakan proses adaptasi terhadap spirit zaman yang berkembang.

Di era yang serba terbuka ini, di mana masyarakat semakin kritis terhadap kebijakan pembangunan yang dilaksanakan oleh Pemerintah maka paradigma pembangunan yang paling sesuai adalah sebuah paradigma yang menjadikan masyarakat sebagai salah satu pelaku dalam setiap proses pembangunan. Masyarakat tidak lagi hanya dipandang sebagai "objek", pandangan kuno bahwa masyarakat tidak mengerti apa-apa terkait dengan pembangunan merupakan pandangan yang sudah usang. Masyarakat memiliki ciri khasnya masing-masing dan kemampuan dalam beradaptasi terhadap lingkungannya (swatata) yang merupakan sebuah potensi besar atau modal dalam proses pelaksanaan pembangunan ke depan.

\section{METODE ANALISIS}

Penelitian ini merupakan peneltian kualitatif dengan menggunakan studi literatur sebagai metode pengumpulan data untuk menelusuri peristiwa yang hendak dikaji dengan pendekatan yang dipilih adalah Analisa Diskursus Kritis (Critical Discourse Analysis) yang mengasumsikan bahwa semua objek dan tindakan adalah penuh makna secara khusus, dan setiap diskursus menunjukkan konstruksi sosial dan politik pada obyek yang diamati. Langkah peran peneliti adalah menyajikan permasalahan, mengumpulkan data historis, mengekstrak kumpulan makna untuk disajikan kembali dalam bentuk analisis hasil kajian pustaka/konseptual.

\section{PEMBAHASAN}

\section{Paradigma Pembangunan di Indonesia}

1. Paradigma Pembangunan Indonesia Era Orde lama

Sejak kemerdekaan hingga tahun 1960an, berbagai upaya perencanaan pembangunan telah dilakukan di Indonesia. Namun tidak satupun dari rencana-rencana tersebut mencapai tahap yang matang dan membuahkan hasil yang memuaskan, yaitu (Tjokroamidjoyo, 1982):

a) Pada tanggal 12 April 1947 dibentuk Panitia Pemikir Siasat Ekonomi yang diketuai oleh Mohammad Hatta. Panitia ini menghasilkan rencana sementara berjudul "Dasar Pokok Dari Pada Plan 
Mengatur Ekonomi Indonesia". Tapi rencana tersebut tidak sempat dilaksanakan karena perjuangan fisik mempertahankan kemerdekaan.

b) Pada bulan Juli tahun 1947 itu juga, di bawah pimpinan I.J. Kasimo dirumuskan "Plan Produksi Tiga Tahun RI". Tapi karena clash I dan II dengan penjajah rencana ini juga tidak sempat dilaksanakan.

c) Kemudian disusun "Rencana Kesejahteraan Istimewa 1950-1951" (untuk bidang pertanian pangan) yang disusul dengan "Rencana Urgensi Untuk Perkembangan Industri 1951-1952" di bawah pimpinan Sumitro Djojohadikusumo. Rencana-rencana ini tidak berjalan dengan baik.

d) Selanjutnya ada pula yang dinamakan "Rencana Pembangunan Lima Tahun 1956-1960" yang disusun oleh Biro Perancang Negara yang diprakarsai oleh Sumitro Djojohadikusumo. Namun pelaksanaannya tertunda hingga tahun 1958 dan pada tahun 1959 sudah diganti dengan rencana baru.

e) Pada tahun 1960 berhasil disusun lagi "Rencana Pembangunan Nasional Semesta Berencana 1961-1969". Namun dalam kenyataannya rencana ini lebih berupa "dokumen politik" dari pada rencana pembangunan dalam arti yang sesungguhnya, tidak realistis, sehingga rencana kurang berjalan baik dan keadaan ekonomi bertambah parah.

f) Dalam keadaan ekonomi yang cukup kritis disusun pula "Perencanaan Ekonomi Perjuangan Tiga Tahun" yang disebut juga "Rencana Banting Stir". Rencana ini tidak pernah terselenggara dengan baik dan tidak mampu menolong parahnya situasi ekonomi.

Akibat tidak satupun rencana pembangunan mendatangkan hasil, keadaan ekonomi Indonesia kian bertambah parah hingga jatuhnya Pemerintahan Soekarno oleh kudeta Gerakan 30 September PKI pada tahun 1965.
2. Paradigma Pembangunan Indonesia Era Orde Baru

Pada masa Orde Baru, pemerintah menjalankan kebijakan yang tidak mengalami perubahan terlalu signifikan selama 32 tahun. Dikarenakan pada masa itu pemerintah sukses menghadirkan suatu stablilitas politik sehingga mendukung terjadinya stabilitas ekonomi. Karena hal itulah maka pemerintah jarang sekali melakukan perubahanperubahan kebijakan terutama dalam hal anggaran negara.

Pada masa pemerintahan Orde Baru, kebijakan ekonominya berorientasi kepada pertumbuhan ekonomi. Kebijakan ekonomi tersebut didukung oleh kestabilan politik yang dijalankan oleh pemerintah. Hal tersebut dituangkan ke dalam jargon kebijakan ekonomi yang disebut dengan Trilogi Pembangungan, yaitu stabilitas politik, pertumbuhan ekonomi yang stabil, dan pemerataan pembangunan.

Hal ini berhasil karena selama lebih dari 30 tahun, pemerintahan mengalami stabilitas politik sehingga menunjang stabilitas ekonomi. Kebijakan-kebijakan ekonomi pada masa itu dituangkan pada Rencana Anggaran Pendapatan dan Belanja Negara (RAPBN), yang pada akhirnya selalu disetujui oleh Dewan Perwakilan Rakyat (DPR) untuk disahkan menjadi APBN.

APBN pada masa pemerintahan Orde Baru, disusun berdasarkan asumsi-asumsi perhitungan dasar. Yaitu laju pertumbuhan ekonomi, tingkat inflasi, harga ekspor minyak mentah Indonesia, serta nilai tukar rupiah terhadap dollar Amerika. Asumsi-asumsi dasar tersebut dijadikan sebagai ukuran fundamental ekonomi nasional. Padahal sesungguhnya, fundamental ekonomi nasional tidak didasarkan pada perhitungan hal-hal makro. Akan tetapi, lebih kearah yang bersifat mikro-ekonomi. Misalnya, masalahmasalah dalam dunia usaha, tingkat resiko yang tinggi, hingga penerapan dunia swasta dan BUMN yang baik dan bersih. Oleh 
karena itu pemerintah selalu dihadapkan pada kritikan yang menyatakan bahwa penetapan asumsi APBN tersebut tidaklah realistis sesuai keadaan yang terjadi.

Format APBN pada masa Orde Baru dibedakan dalam penerimaan dan pengeluaran. Penerimaan terdiri dari penerimaan rutin dan penerimaan pembangunan serta pengeluaran terdiri dari pengeluaran rutin dan pengeluaran pembangunan. Sirkulasi anggaran dimulai pada 1 April dan berakhir pada 31 Maret tahun berikutnya. Kebijakan yang disebut tahun fiskal ini diterapkan seseuai dengan masa panen petani, sehingga menimbulkan kesan bahwa kebijakan ekonomi nasional memperhatikan petani.

APBN pada masa itu diberlakukan atas dasar kebijakan prinsip berimbang, yaitu anggaran penerimaan yang disesuaikan dengan anggaran pengeluaran sehingga terdapat jumlah yang sama antara penerimaan dan pengeluaran. $\mathrm{Hal}$ perimbangan tersebut sebetulnya sangat tidak mungkin, karena pada masa itu pinjaman luar negeri selalu mengalir. Pinjamanpinjaman luar negeri inilah yang digunakan pemerintah untuk menutup anggaran yang defisit.

Ini artinya pinjaman-pinjaman luar negeri tersebut ditempatkan pada anggaran penerimaan. Padahal seharusnya pinjamanpinjaman tersebut adalah utang yang harus dikembalikan, dan merupakan beban pengeluaran di masa yang akan datang. Penerapan kebijakan tersebut menimbulkan banyak kritik, karena anggaran defisit negara ditutup dengan pinjaman luar negeri. Padahal, konsep yang benar adalah pengeluaran pemerintah dapat ditutup dengan penerimaan pajak dalam negeri. Sehingga antara penerimaan dan pengeluaran dapat berimbang. Permasalahannya, pada masa itu penerimaan pajak saat minim sehingga tidak dapat menutup defisit anggaran.
3. Paradigma Pembangunan Indonesia Era Reformasi

Pada masa krisis ekonomi, ditandai dengan tumbangnya pemerintahan Orde Baru kemudian disusul dengan era Reformasi yang dimulai oleh pemerintahan Presiden Habibie. Pada masa ini tidak hanya hal ketatanegaraan yang mengalami perubahan, namun juga kebijakan ekonomi. Sehingga apa yang telah stabil dijalankan selama 32 tahun, terpaksa mengalami perubahan guna menyesuaikan dengan keadaan.

Pemerintahan Presiden BJ.Habibie yang mengawali masa reformasi belum melakukan manuver-manuver yang cukup tajam dalam bidang ekonomi. Kebijakan-kebijakannya diutamakan untuk mengendalikan stabilitas politik. Pada masa kepemimpinan Presiden Abdurrahman Wahid pun, belum ada tindakan yang cukup berarti untuk menyelamatkan negara dari keterpurukan. Padahal, ada berbagai persoalan ekonomi yang diwariskan orde baru harus dihadapi, antara lain masalah KKN (Korupsi, Kolusi dan Nepotisme), pemulihan ekonomi, kinerja BUMN, pengendalian inflasi, dan mempertahankan kurs rupiah. Malah presiden terlibat skandal Bruneigate yang menjatuhkan kredibilitasnya di mata masyarakat. Akibatnya, kedudukannya digantikan oleh presiden Megawati.

Masa kepemimpinan Megawati Soekarnoputri mengalami masalah-masalah yang mendesak untuk dipecahkan adalah pemulihan ekonomi dan penegakan hukum. Kebijakan-kebijakan yang ditempuh untuk mengatasi persoalan-persoalan ekonomi antara lain :

a) Meminta penundaan pembayaran utang sebesar US\$ 5,8 milyar pada pertemuan Paris Club ke-3 dan mengalokasikan pembayaran utang luar negeri sebesar $\mathrm{Rp}$ 116.3 triliun.

b) Kebijakan privatisasi BUMN. Privatisasi adalah menjual perusahaan negara di dalam periode krisis dengan tujuan 
melindungi perusahaan negara dari intervensi kekuatan-kekuatan politik dan mengurangi beban negara. Hasil penjualan itu berhasil menaikkan pertumbuhan ekonomi Indonesia menjadi 4,1\%. Namun kebijakan ini memicu banyak kontroversi, karena BUMN yang diprivatisasi dijual ke perusahaan asing.

Di masa ini juga direalisasikan berdirinya KPK (Komisi Pemberantasan Korupsi), tetapi belum ada gebrakan konkrit dalam pemberantasan korupsi. Padahal keberadaan korupsi membuat banyak investor berpikir dua kali untuk menanamkan modal di Indonesia, dan mengganggu jalannya pembangunan nasional.

Masa Kepemimpinan Susilo Bambang Yudhoyono terdapat kebijakan kontroversial yaitu mengurangi subsidi BBM, atau dengan kata lain menaikkan harga BBM. Kebijakan ini dilatar belakangi oleh naiknya harga minyak dunia. Anggaran subsidi BBM dialihkan ke subsidi sektor pendidikan dan kesehatan, serta bidang-bidang yang mendukung peningkatan kesejahteraan masyarakat.

Kebijakan kontroversial pertama itu menimbulkan kebijakan kontroversial kedua, yakni Bantuan Langsung Tunai (BLT) bagi masyarakat miskin. Kebanyakan BLT tidak sampai ke tangan yang berhak, dan pembagiannya menimbulkan berbagai masalah sosial. Kebijakan yang ditempuh untuk meningkatkan pendapatan perkapita adalah mengandalkan pembangunan infrastruktur massal untuk mendorong pertumbuhan ekonomi serta mengundang investor asing dengan janji memperbaiki iklim investasi. Salah satunya adalah diadakannya Indonesian Infrastructure Summit pada bulan November 2006, yang mempertemukan para investor dengan kepala-kepala daerah.

Pada pertengahan bulan Oktober 2006 , Indonesia melunasi seluruh sisa utang pada
IMF sebesar 3,2 miliar dolar AS. Dengan ini, maka diharapkan Indonesia tak lagi mengikuti agenda-agenda IMF dalam menentukan kebijakan dalam negeri. Namun wacana untuk berhutang lagi pada luar negri kembali mencuat, setelah keluarnya laporan bahwa kesenjangan ekonomi antara penduduk kaya dan miskin menajam, dan jumlah penduduk miskin meningkat dari 35,10 jiwa di bulan Februari 2005 menjadi 39,05 juta jiwa pada bulan Maret 2006.

Hal ini disebabkan karena beberapa hal, antara lain karena pengucuran kredit perbankan ke sektor riil masih sangat kurang (perbankan lebih suka menyimpan dana di SBI), sehingga kinerja sektor riil kurang dan berimbas pada turunnya investasi. Selain itu, birokrasi pemerintahan terlalu kental, sehingga menyebabkan kecilnya realisasi belanja Negara dan daya serap, karena inefisiensi pengelolaan anggaran. Jadi, di satu sisi pemerintah berupaya mengundang investor dari luar negri, tapi di lain pihak, kondisi dalam negeri masih kurang kondusif.

Pada masa Reformasi ini proses pembangunan nasional memang sudah demokratis dan sudah memerankan fungsi pemerintah daerah dalam menjalankan pasipartisi rakyat daerahnya. Dengan peluang otonomi daerah telah memberikan sumbangsi yang besar terhadap proses percepatan pembangunan nasional dan juga menjaminnya sistem demokrasi yang merakyat.

\section{Reorientasi Paradigma Pembangunan di Indonesia}

Beberapa paradigma pembangunan telah mengisyaratkan bahwa penerapan teori maupun paradigma pembangunan ekonomi di Indonesia telah mengalami beberapa kali perubahan (penyempurnaan). Teori Modernisasi terutama menekankan pada faktor manusia dan nilai-nilai budayanya sebagai pokok persoalan dalam pembangunan. Teori Modernisasi merupakan 
kelompok teori yang dominan dalam mengkaji masalah pembangunan di Indonesia. Teori ini dianut baik di kalangan ahli ilmu sosial (termasuk ahli ilmu ekonomi) maupun oleh para pejabat tinggi negara (Budiman, 2000).

Dari segi teori pembangunan, pernyataan Budiman (2000) tersebut memang ada benarnya, tetapi masih harus diperjelas bahwa pernyataan itu lebih tepatnya untuk pembangunan di masa Orde Baru (sejak awal tahun 1970-an), yang menerapkan planned economy dengan pola "Growth First then Distribution of Wealth" atau yang lebih dikenal dengan strategi trickle down effects, terutama mengadopsi dari model Rostow yang lebih mengedepankan economic growth daripada faktor manusia dan nilai-nilai budaya sebagai pokok persoalan pembangunan. Indikasinya terlihat jelas, selain pada pentahapan pembangunan (pertumbuhan dan tingggal landas), kebijakan ekonomi konglomerasi, dan munculnya elite-elite politik yang ngathok pada penguasa demi meraih prestise ekonomi (kekayaan), di samping marginalisasi rakyat kecil dan buruh.

Secara teoretis, memang Rostow mengartikan pembangunan ekonomi sebagai suatu proses yang menyebabkan perubahan dalam masyarakat, yaitu perubahan politik, struktur sosial, nilai sosial dan struktur kegiatan ekonominya (Suryana, 2000), sehingga dalam menggenjot keberhasilan pembangunan ekonomi diperlukan elite baru yang bernama konglomerat yang akan menjadi tenaga pendorong untuk melakukan pembaruan. Elite baru inilah, menurut Budiman (2000), merupakan kelompok orang yang frustasi (dalam arti positif), karena tatanan sosial-politik yang ada tidak memberi kemungkinan untuk mengembangkan diri. Ini misalnya terjadi pada kelompok pedagang di jaman feodal, orang-orang Yahudi di Eropa, atau orang-orang Cina di Asia Tenggara. Karena tidak bisa memajukan diri di jalur sosial-politik, mereka bergerak di bidang ekonomi dan kemudian mendapatkan tempat terhormat karena keberhasilannya mengumpulkan kekayaan.

Dalam merancang dan mengimplementasikan program-program pembangunan, rezim Orde Baru menerapkan pola top down di mana semuanya berasal dari atas (pemerintah), dan sangat mengabaikan pola bottom up. Dengan demikian, hampir tak ada ruang publik bagi masyarakat untuk berpartisipasi, termasuk dalam turut mempengaruhi kebijakan - kebijakan pembangunan. Alternatif model pelaksanaan pembangunan di luar yang ditawarkan negara, dapat dikatakan nihil (Azis dan Tim CPPS, 2001).

Adopsi pendekatan pembangunan yang diarahkan pada strategi trickle down effects dengan pola konglomerasinya Orde Baru, ternyata tidak dapat berjalan sebagaimana teorinya. "Efek-efek" yang menetes ke bawah yang diharapkan mampu menjunjung golongan miskin dan ekonomi lemah, ternyata malah sebaliknya. Golongan ekonomi lemah menjadi sangat tergantung pada struktur ekonomi di atasnya, karena memang sistem ekonominya mengikat pada hal seperti itu. Ingat keputusan Jimbaran yang hanya sekedar retorika konglomerat belaka, kebijakan perbankan yang mewajibkan $20 \%$ kreditnya untuk pengusaha kecil dan mikro pun ternyata juga retorika belaka. Yang ada justru para konglomerat ngemplang dana BLBI.

Strategi economic growth dengan pola konglomerasi juga menghasilkan dampak yang mengerikan, yaitu bahwa pertumbuhan tinggi namun kesenjangan antara yang kaya dan miskin semakin lama semakin jauh. Si kaya semakin kaya dan si miskin semakin miskin. Akibatnya adalah tidak tertampungnya kapasitas ekonomi kelas bawah dalam dinamika ekonomi nasional yang lebih sehat. Kesimpulan hasil penelitian tim Akatiga (t.th) pada Masyarakat Mikung sedikit bisa menjadi bukti nyata, bahwa 
model pembangunan yang bersifat top-down dan mengejar pertumbuhan ekonomi secara fisik pada gilirannya telah memarjinalkan dan memiskinkan kelompok-kelompok tertentu dalam masyarakat. Pada kasus tertentu, seperti yang terjadi pada Kelompok Mikung dalam masyarakat Kampung Gunung Tanjung Tengah, proses pemarjinalan terjadi selain karena faktor struktural akibat model pembangunan pemerintah tersebut juga disebabkan karena faktor perbedaan ideologi agama antar kelompok di dalam masyarakat. Kedua faktor tersebut bekerja demikian kuat dalam kehidupan masyarakat seiring dengan perubahan sistem politik nasional mulai dari masa Orde Lama hingga Orde Baru.

Kondisi seperti ini mengakibatkan weak economic foundation (fondasi ekonomi yang lemah) karena tidak terdistribusikannya kekuatan ekonomi secara proporsional dan seimbang. Keadaan ini semakin diperparah dengan budaya KKN (economic corruption, collusion, cronyism) dan unfair economic competition oleh karena intervensi kekuasaan dalam kehidupan ekonomi. Idealisme dalam kebijakan tidak pernah cocok dalam implementasinya, kebijakan menyatakan pembangunan ekonomi untuk membantu masyarakat kecil, namun pada kenyataannya masyarakat ekonomi menengah dan ke atas yang diuntungkan (Yuwono, 1999). Dampaknya telah terbukti perekonomian yang telah dibangun seperempat abad hancur sekejap hanya dengan sekali krismon (krisis moneter), bahkan berakibat krisis ekonomi yang berkepanjangan.

Oleh karena itulah paradigma pembangunan ekonomi yang jelas-jelas terbukti membawa sengsara bagi negara dan sebagian besar rakyat Indonesia itu harus benar-benar direformasi. Bukankah Bung Karno, salah satu founding father bangsa Indonesia, terkenal dengan salah satu ucapannya "jangan sekali-sekali melupakan sejarah". Hal ini penting sekali bagi siapapun, karena dari sejarahlah dapat belajar kegagalan sebelumnya untuk kemudian menyusun strategi baru yang lebih rasional.

Bertolak dari pengalaman sejarah yang pahit itu, barang kali pemikiran Dillon (2001) dapat dicermati. Menurut Dillon (2001), guna menjamin terciptanya fundamental ekonomi yang solid untuk pertumbuhan yang berkelanjutan pada masa mendatang, maka strategi pengembangan ke depan harus didasarkan pada kekuatan sumberdaya domestik. Selagi kita merupakan masyarakat agraris dengan jumlah penduduk yang sangat besar, maka peningkatan produktivitas pertanian tidak boleh terlepas dari proses peningkatan penghasilan petani, usaha kecil dan menengah (UKM), upah buruh serta pembangunan perdesaan. Dari sinilah titik tolak kita dalam mengelola pembentukan modal domestik. Dengan demikian, setiap tahapan transformasi struktural akan dapat dilalui dengan baik, menuju masyarakat industri dan jasa dengan nilai tambah yang tinggi secara proporsional kelak. Kita harus mampu merakit kebijakan dan kelembangan sedemikian rupa sehingga pola pembentukan modal senantiasa terarah pada peningkatan produktivitas mayoritas warga bangsa. Pertumbuhan ekonomi yang tinggi tetap merupakan sasaran utama, tetapi yang lebih penting adalah menetapkan sumber dari pertumbuhan karena pilihan tersebut akan menyangkut keberdayaan pelaku utama ekonomi, seperti petani, buruh, dan UKM. Elemen strategis untuk mendukung hal tersebut antara lain paradigma pembangunan yang bermuara pada otonomi rakyat, transformasi kelembagaan ekstraktif menjadi kelembagaan yang representatif, infrastruktur fisik dan sosial yang mensenyawakan kota dengan perekonomian perdesaan, pasar modal di perdesaan yang dapat dijangkau semua orang, dan politik pertanahan yang lebih adil bagi penduduk setempat.

Namun rupanya tim ekonomi pemerintahan sekarang ini masih bangga bila angka pertumbuhan ekonomi meningkat, tapi 
masih enggan mengakui meningkatnya angka kemiskinan. Oleh karena itu perlu adanya komitmen pemerintah untuk berkonsentrasi penuh pada pengelolaan pembangunan yang menempatkan rakyat sebagai aktor, terutama pembangunan ekonomi yang lebih berpihak pada rakyat sebagaimana amanat UUD 1945 (penjelasan pasal 33), yaitu pengutamaan kemakmuran masyarakat bukan kemakmuran orang seorang.

Memanglah ekonomi kerakyatan hampir tak tersentuh oleh para ahli ekonomi, bahkan nyaris terlupakan, karena dalam ilmu ekonomi sendiri yang dipelajari hanyalah teori-teori ekonomi mikro dan makro yang bersumber dari negara-negara industri maju dengan ukuran yang relatif besar. Padahal mayoritas penduduk Indonesia adalah petani, nelayan, tukang sayur, tukang becak, tukang rombeng, pedagang kaki lima, pedagang keliling, dan sebagainya. Ekonomi Rakyat adalah usaha ekonomi yang tegas-tegas tidak mengejar keuntungan tunai, tetapi dilaksanakan untuk (sekedar) memperoleh pendapatan bagi pemenuhan kebutuhan keluarga secara langsung untuk memenuhi kebutuhan pangan, sandang, papan, dan kebutuhan-kebutuhan keluarga lain yang semuanya mendesak untuk dipenuhi (Mubyarto, 2002).

Oleh karena itu jika banyak orang berpendapat bahwa paradigma ekonomi kerakyatan merupakan paradigma baru yang mulai populer bersama reformasi, sehingga masuk dalam Propenas, hal itu bisa dimengerti karena kata "ekonomi kerakyatan" sangat jarang dijadikan wacana sebelumnya. Namun, jika pendapat yang demikian itu diterima, bahwa paradigma ekonomi kerakyatan merupakan paradigma baru yang mereaksi paradigma ekonomi konglomerasi (kapitalis liberal) yang dijadikan pegangan era ekonomisme Orde Baru, maka yang terjadi adalah reaksi kembali khususnya dari para ekonom yang menganggap tak ada yang salah dengan sistem ekonomi Orde
Baru, berarti yang salah adalah praktek pelaksanaannya bukan pada teorinya.

Padahal kenyataannya, ekonomi rakyat sebagai mata pencaharian sebagian besar rakyat memiliki daya tahan tinggi terhadap ancaman dan goncangan badai krisis ekonomi 1997-1998 lalu. Sejarah pun, kata Mubyarto (2002), membuktikan bahwa ketika terjadi depresi pada tahun 1920-an dan 1930an di mana perkebunan-perkebunan besar Belanda merugi karena anjlognya harga internasional, justru perkebunan rakyatlah yang menikmatinya.

\section{Paradigma Pembangunan Indonesia Kedepannya}

Hingga dekade 1980-an teori dan praktik pembangunan sangat didominasi oleh paradigma Neo-Klasik yang mengejar pertumbuhan ekonomi (economic growth) yang dikotomis, karena di satu sisi memperhitungkan efisiensi penggunaan modal, tenaga kerja, gandrung pada efisiensi teknologi namun di sisi lain susutnya sumberdaya alam dan rusaknya lingkungan tidak diperhitungkan dalam akuntansi pembangunan (Development Accounting).

Kemudian kenyataan empirik membuktikan bahwa pertumbuhan ekonomi yang terjadi sesungguhnya bersifat semu bahkan dalam jangka panjang menghasilkan kalkulasi yang negatif. Manakala telah sampai pada deplesi sumberdaya alam disertai parahnya destruksi lingkungan pertumbuhan ekonomi menjadi terhambat bahkan menjadi negatif.

Karena itu para pakar perencanaan pembangunan yang menganut faham environmentalist mulai memikirkan konsep dan strategi baru dari pembangunan yang mampu menghasilkan pertumbuhan ekonomi namun konservasi lingkungan tetap terpelihara dengan baik. Perubahan persepsi tersebut dikenal dengan istilah Sustainable Development atau Pembangunan Berkelanjutan. Sejak tahun 1987 beberapa 
definisi dari Pembangunan Berkelanjutan disepakati dan penerapan teori dan prinsipnya pun ditetapkan.

Empat puluh tahun terakhir Indonesia menganut paradigma pembangunan yang tipikal mengeksploitasi sumberdaya alam dengan segala dampak negatifnya terhadap lingkungan. Itupun hanya mampu menghasilkan pertumbuhan ekonomi yang tidak lebih dari 7 persen dan sulit dipertahankan. Susutnya sumberdaya alam seperti minyak, bahan tambang, hutan nyaris bagi Indonesia untuk tidak dapat melanjutkan pembangunan. Karena itu mau tidak mau paradigma lama harus mulai ditinggalkan sebelum mencapai kebntuan (development dead-lock). Paradigma baru yang lebih sustainable harus mulai dirintis dan diimplementasikan sehingga mampu menciptakan modus-modus ekonomi baru yang mampu menciptakan pertumbuhan ekonomi yang cukup tinggi dengan dampak negatif yang seminimal mungkin terhadap destruksi lingkungan. Maka paradigma yang tepat untuk pembangunan Indonesia adalah "Pembangunan Berkelanjutan (Sustanaible Development)" sebagaimana dijelaskan dibawah ini :

1. Lahirnya Paradigma Pembangunan Berkelanjutan

Konsep pembangunan berkelanjutan pertama kali dipublikasikan oleh The World Concervation Strategy (WCS) pada tahun 1980 di Gland, Swiss dan menjadi pusat pemikiran untuk pembangunan dan lingkungan. Pada WCS tersebut, pembangunan berkelanjutan didefinisikan sebagai berikut : "Sustainable development - maintenance of essential ecological processes and life support systems, the preservation of genetic diversity, and the sustainable utilization of species and ecosystems". Definisi lain yang terkenal dikemukakan oleh World Commission on Environtment and Development (WCED) 1978, yang dikenal pula dengan nama Komisi Bruntland, adalah "pembangunan yang memenuhi generasi kini tanpa membahayakan generasi mendatang untuk dapat memenuhi sendiri kebutuhan mereka".

Sampai dengan dekade 1980-an perencanaan dan strategi pembangunan masih berorientasi pada pertumbuhan ekonomi (economic growth), baik pada negaranegara sosialis yang menerapkan perencanaan yang terpusat maupun pada negara-negara kapitalis yang menerapkan perencanaan yang liberal. Filosofi pertumbuhan ekonomi dilatarbelakangi oleh Teori Neo-Klasik dimana pertumbuhan merupakan fungsi dari modal dan teknologi sedangkan sumberdaya alam sama sekali tidak diperhitungkan karena dianggap pemberian alam yang melimpah. Filosofi tersebut telah melahirkan berbagai ekses terhadap lingkungan, sosial, budaya, maupun hak asasi manusia. Dampak dari penerapan filosofi tersebut telah menimbulkan kemiskinan yang merajalela, rusaknya ekosistem, pencemaran, bahkan ancaman terhadap eksistensi manusia dan kemanusiaan (Pearce and Warford, 1993).

Pengalaman hingga tahun 1980-an memperlihatkan bahwa hambatan pertumbuhan ekonomi terjadi apabila faktor sumberdaya alam dan lingkungan tidak dikelola dengan baik. Jika ekonomi dan lingkungan dikelola dengan baik maka pertumbuhan ekonomi akan terjadi dalam lingkungan yang terpelihara kelestariannya. Perubahan persepsi di atas dikenal dengan istilah Sustainable Development sebagai babak baru dari teori pembangunan dan sekaligus mengakhiri perdebatan antara pertumbuhan ekonomi dan penyelamatan lingkungan.

2. Konsep Pembangunan Berkelanjutan

Pembangunan berkelanjutan (Emil Salim, 1990) bertujuan untuk meningkatkan kesejahteraan masyarakat, untuk memenuhi kebutuhan dan aspirasi manusia. Pembangunan yang berkelanjutan pada hekekatnya ditujukan untuk mencari pemerataan pembangunan antar generasi pada masa kini maupun masa mendatang. 
Menurut KLH (1990) pembangunan (yang pada dasarnya lebih berorientasi ekonomi) dapat diukur keberlanjutannya berdasarkan tiga kriteria yaitu: (1) tidak ada pemborosan penggunaan sumber daya alam atau depletion of natural resources, (2) tidak ada polusi dan dampak lingkungan lainnya, (3) kegiatannya harus dapat meningkatkan useable resources ataupun replaceable resource.

Dalam beberapa literatur ada kesepakatan bahwa pembangunan berkelanjutan mengimplikasikan hubungan terkait mengenai apa yang harus dipertahankan dengan apa yang harus dibangun, tetapi juga, penekanan sering berbeda yang dari "hanya mempertahankan" untuk "sebagian besar membangun" kepada berbagai bentuk dari "dan/atau." Demikian pula, jangka waktunya, tegas dinyatakan bahwa definisi standar sebagai "sekarang dan dimasa mendatang," telah berbeda secara luas. Ini telah ditetapkan dari yang sedikit dari generasi, dimana hampir semuanya berkelanjutan, hingga selamanya, padahal kenyataannya tidak ada yang berkelanjutan.

Dalam pembangunan berkelanjutan terdapat tiga komponen utama yaitu sosial, ekonomi dan lingkungan. Setiap komponen tersebut saling berhubungan dalam satu sistem yang dipicu oleh kekuatan dan tujuan. Sektor sosial bertujuan untuk meningkatkan hubungan antar manusia, pencapaian aspirasi individu dan kelompok, dan penguatan nilai. Sektor ekonomi untuk melihat pengembangan sumber daya manusia, khususnya melalui peningkatan konsumsi barang-barang dan jasa pelayanan. Sektor lingkungan difokuskan pada perlindungan integritas sistem ekologi (Munasinghe 2002).

Haris (2000) melihat bahwa konsep keberlajutan dapat diperinci menjadi tiga aspek pemahaman, (1) keberlajutan ekonomi yang diartikan sebagai pembangunan yang mampu menghasilkan barang dan jasa secara kontinu untuk memelihara keberlajutan pemerintahan dan menghindari terjadinya ketidakseimbangan sektoral yang dapat merusak produksi pertanian dan industri, (2) keberlajutan lingkungan: Sistem keberlanjutan secara lingkungan harus mampu memelihara sumber daya yang stabil, menghindari eksploitasi sumber daya alam dan fungsi penyerapan lingkungan. Konsep ini juga menyangkut pemeliharaan keanekaraman hayati, stabilitas ruang udara, dan fungsi ekosistem lainnya yang tidak termasuk kategori sumber-sumber ekonomi, (3) keberlajutan sosial, keberlanjutan secara sosial diartikan sebagai sistem yang mampu mencapai kesetaraan, penyediaan layanan sosial termasuk kesehatan, pendidikan, gender, dan akuntabilitas politik.

Dengan menjelaskan pengertian

pembangunan berkelanjutan serta menerangkan implikasi dibaliknya, Komisi Bruntland kemudian mengidentifikasikan tujuh tujuan penting untuk kebijakan pembangunan dan lingkungan. Ketujuh tujuan tersebut, yaitu meliputi: memikirkan kembali makna pembangunan, (2) mengubah kualitas pertumbuhan (lebih menekankan pada pembangunan dari pada sekedar pertumbuhan), (3) memenuhi kebutuhan dasar akan lapangan kerja, makanan, energi, air dan sanitasi, (4) menjamin terciptanya keberlanjutan pada satu tingkat pertumbuhan penduduk tertentu, (5) mengkonversi dan meningkatkan sumber daya, (6) mengubah arah teknologi dan mengelola resiko; dan (7) memadukan pertimbangan lingkungan dan ekonomi dalam pengambilan keputusan.

3. Penerapan Konsep Pembangunan Berkelanjutan

Secara teoritis prinsip-prinsip pembangunan berkelanjutan dapat diterapkan pada berbagai sektor pembangunan. penerapan konsep, prinsip dan tujuan pembangunan bekelanjutan dalam pembangunan secara luas dapat dilakukan dengan menetapkan kaidah-kaidahnya 
(Djajadiningrat, 1992; Pearce and Warford, 1993):

\section{a) Pemerataan dan Keadilan (Equity and Justice)}

Pemerataan dan keadilan di sini menyangkut dimensi etika, yakni adanya kesenjangan antara Negara ataupun daerah yang kaya dan miskin serta masa depan generasi mendatang yang tidak dapat dikompromikan dengan kegiatan generasi masa kini. Karena itu aspek pemerataan dan keadilan ini harus dijawab baik untuk generasi masa kini maupun untuk generasi mendatang. Karena itu strategi dan perencanaan pembangunan harus dilandasi premis seperti: distribusi penguasaan lahan, distribusi faktor-faktor produksi, pemerataan peran dan kesempatan kaum wanita, kelompok marjinal, dan lain sebagainya.

\section{b) Pendekatan Integratif (Integrative Approach)}

Pembangunan

berkelanjutan mengutamakan keterkaitan antara manusia dengan alam. Manusia mempengaruhi alam dengan cara-cara yang bermanfaat atau merusak. Keberlanjutan masa depan hanya dimungkinkan bila pengertian tentang kompleksnya keterkaitan antara sistem alam dan sosial dapat dipahami dan cara-cara yang integrative (terpadu) diterapkan dalam perencanaan dan pelaksanaan pembangunan.

c) Perspektif Jangka Panjang (Long Term Perspective)

Pembangunan

berkelanjutan

mensyaratkan dilaksanakan penilaian yang berbeda dengan asumsi normal dalam prosedur pengenaan discounting. Perspektif jangka panjang merupakan visi dari pembangunan berkelanjutan sedangkan saat ini visi jangka pendek masih mendominasi dalam pengambilan keputusan.

\section{d) Keberlanjutan Ekologis (Ecological Sustainability)}

Keberlanjutan ekologis menjamin keberlanjutan eksistensi bumi. Untuk menjamin keberlanjutan ekologis integritas tatanan lingkungan harus dipelihara melalui upaya-upaya peningkatan daya dukung, daya asimilasi, dan keberlanjutan pemanfaatan sumberdaya yang dapat dipulihkan (renewable resources).

e) Keberlanjutan Ekonomi (Economic Sustainability)

Menjamin kemajuan ekonomi secara berkelanjutan dan mendorong efisiensi ekonomi. Tiga unsur utama untuk mencapai keberlanjutan ekonomi makro yaitu efisiensi ekonomi, kesejahteraan ekonomi yang berkesinambungan, serta meningkatkan kemakmuran dan distribusi kemakmuran.

f) Keberlanjutan Sosial Budaya (SocialCultural Sustainability)

Secara menyeluruh keberlanjutan sosial dan budaya dinyatakan dalam keadilan sosial, harga diri manusia, dan peningkatan kualitas hidup seluruh manusia. Keberlanjutan segi sosial budaya mempunyai sasaran: stabilitas penduduk, pemenuhan kebutuhan dasar manusia, memelihara keanekaragaman budaya, serta mendorong partisipasi masyarakat local dalam pengambilan keputusan.

\section{g) Keberlanjutan Politik (Political Sustainability)}

Keberlanjutan politik dicirikan dengan adanya penghormatan terhadap hak asasi manusia, demokrasi, serta kepastian kesediaan pangan, air dan pemukiman.

h) Keberlanjutan Pertahanan dan Keamanan (Defense and Security Sustainability).

Keberlanjutan kemampuan menghadapi dan mengatasi tantangan, ancaman, gangguan baik dari dalam maupun dari luar yang langsung dan tidak langsung dapat membahayakan integritas, identitas, keberlangsungan negara dan bangsa.

Implementasi dari kedelapan kaidah di atas sejauh ini dapat dikelompokan ke dalam tiga kelompok analisa, yaitu analisa biaya ekonomi (economic cost analysis), analisa biaya lingkungan (environmental cost analysis), dan analisa biaya sosial (sosial cost analysis). Suatu 
perencanaan proyek-proyek pembangunan yang dikatakan berkelanjutan (sustainable) harus dibuktikan dengan analisa, bahwa manfaat atau benefit lebih besar dari cost (economic cost + environmental cost + sosial cost), atau bila sebaliknya, proyek-proyek pembangunan tersebut dikatakan tidak berkelanjutan.

4. Indikator Pembangunan Berkelanjutan indikator-indikator pembangunan bekelanjutan adalah sebagai berikut :

a) Melestarikan sistem-sistem pendukung kehidupan dan keanekaragaman hayati: (1) kemajuan dalam pencegahan pencemaran, (2) kemajuan dalam memulihkan dan memepertahankan integritas ekosistem, (3) kemajuan dalam mengembangkan sistem daerah suaka yang komprehensif, (4) kemajuan dalam memulihkan dan mempertahankan spesies dan sediaan genetik.

b) Menjamin keberlanjutan penggunaan sumberdaya yang dapat diperbarui dan meminimkan penipisan sumberdaya yang tak dapat diperbarui: (1) status atau kondisi sumberdaya suatu sektor, (2) status atau kondisi infrasruktur ekologi suatu sektor, (3) kesesuaian dan pertentangan antara suatu sektor dengan keberlanjutan sektorsektor lainnya

c) Berusaha tidak melampaui daya dukung ekosistem: (1) konsumsi pangan, air, kayu, mineral per kapita, (2) pola pertumbuhan penduduk, (3) laju fertilitas total, (4) kerapatan penduduk.

\section{KESIMPULAN}

Dalam sejarahnya Indonesia telah mengimplementasikan beberapa paradigma pembangunan yang ada di dunia dengan ciri khasnya masing-masing, mulai dari paradigma liberal yang erat kaitannya dengan modernisasi dan paradigma Marxis dengan konsep pemberdayaannya. Paradigma pembangunan yang dijalankan tersebut merupakan proses adaptasi terhadap spirit zaman yang berkembang. Paradigma pembangunan yang diterapkan di Indonesia dari masa orde, orde baru, hingga orde reformasi belum mampu menghantarkan bangsa Indonesia menjadi Negara maju atau bangsa yang bedaulat atas masyarakatnya. Di era yang serba terbuka ini, di mana masyarakat semakin kritis terhadap kebijakan pembangunan yang dilaksanakan oleh Pemerintah maka paradigma pembangunan yang paling sesuai adalah sebuah paradigma yang menjadikan masyarakat sebagai salah satu pelaku dalam setiap proses pembangunan. Maka paradigma yang dianggap tepat untuk pembangunan Indonesia adalah Pembangunan Berkelanjutan (Sustanaible Development).

Konsep pembangunan berkelanjutan mengandung tiga aspek pemahaman, yakni 1) keberlanjutan lingkungan, 2) keberlanjutan ekonomi, 3) keberlanjutan sosial dengan penerapan konsep, prinsip dan tujuan pembangunan bekelanjutan dalam pembangunan secara luas dapat dilakukan dengan menetapkan kaidah-kaidahnya antara lain : 1) Pemerataan dan Keadilan (Equity and Justice), 2) Pendekatan Integratif (Integrative Approach), 3) Perspektif Jangka Panjang (Long Term Perspective), 4) Keberlanjutan Ekologis (Ecological Sustainability), 5) Keberlanjutan Ekonomi (Economic Sustainability), 6) Keberlanjutan Sosial Budaya (Social-Cultural Sustainability), 7) Keberlanjutan Politik (Political Sustainability), 8) Keberlanjutan Pertahanan dan Keamanan (Defense and Security Sustainability). Sedangkan indikator pembangunan berkelanjutan adalah : 1) Melestarikan sistem-sistem pendukung kehidupan dan keanekaragaman hayati, 2) Menjamin keberlanjutan penggunaan sumberdaya yang dapat diperbarui dan meminimkan penipisan sumberdaya yang tak dapat diperbarui, 3) Berusaha tidak melampaui daya dukung ekosistem. 


\section{REFERENSI}

Bjorn, Hettne. 1982. Ironi Pembangunan di Negara Berkemban. Sinar Harapan, Jakarta.

Budiman, Arief. 2000. Teori Pembangunan Dunia Ketiga. Jakartam PT Gramedia Pustaka Utama.

Haris, 2000, Konsep Pembangunan Ekonomi yang Berkelanjutan, Tiga Aspek Pemahaman Ekonomi berkelanjutan.

Ginanjar, Kartasasmita. 1997. Kemiskinan. Jakarta, Balai Pustaka.

KLH. 1989. Keanekaragaman Hayati untuk Kelangsungan Hidup Bangsa. Menteri Negara Kependudukan dan Lingkungan Hidup. Jakarta.

Mubyarto. 2002. Pemberdayaan Ekonomi Rakyat dan Peranan ilmu-ilmu Sosial. Yogyakarta.

Munasinghe, M. 2002. 'Analyisng the Nexus of Sutainable Development and Climate Change: An Overview', pp. 1-53.

Pearce, D, Warford, J.J. 1993. World Without End : Economics, Environment, and Sustainable Development. Oxford University Press. New York.

Suryana, 2000. Ekonomi Pembangunan: Problematika serta Pendekatan, Jakarta: Salemba Empat.

Suryono, Agus. 2001. Teori dan Isu Pembangunan. Jakarta, UM-Press.

Tjokrowinoto, Moeljarto. 1999. Pembangunan : Dilema dan Tantangan. Yogyakarta, Pustaka Pelajar.

Tjokroamidjojo, Bintoro. (1978) Pengantar Administrasi Pembangunan. LP3ES. Jakarta.

Todaro, Michael, P. 2000. Pembangunan Ekonomi di Dunia Ketiga. Edisi Ketujuh diterjemahkan oleh Haris Munandar. Penerbit Erlangga. Jakarta 